\title{
Effect of Different Growing Media on Seedling Growth Parameters and Economics of Papaya (Carica papaya L) cv. Pusa Delicious
}

\author{
A.K. Meena, O.P. Garhwal, Arun Kumar Mahawar* and S.P. Singh \\ Department of Horticulture, SKN College of Agriculture, Jobner - 303329, \\ Jaipur (Rajasthan), India \\ *Corresponding author
}

\section{A B S T R A C T}

\section{Keywords \\ Papaya, Cocopeat, Vermiculite, \\ Vermicompost, Growth and net returns. \\ Article Info \\ Accepted: \\ 29 May 2017 \\ Available Online: \\ 10 June 2017}

The experiment was conducted to study the "Effect of different growing media on seedling growth parameters and economics of papaya (Carica papaya L) cv. Pusa Delicious" at Departmental Nursery and Horticulture farm, S.K.N. College of Agriculture, Jobner, Rajasthan during 2014-15. The treatments were prepared with combination between types of media with level of cocopeat having 50 polybags in each treatment and replication. The results showed that the medium of soil + vermicompost + vermiculite $(1: 1: 1)$ with $2 \mathrm{~cm}$ cocopeat at top of polybags $\left(\mathrm{T}_{5}\right)$ found to be the best and significantly superior medium for the growth of papaya seedlings as it gave the highest growth parameters in terms of stem girth (4.49 $\mathrm{mm}$ and $5.90 \mathrm{~mm}$ at 30 and 45 DAS, respectively), number of roots (16.06), root length $(9.07 \mathrm{~cm})$, fresh weight of shoot and root $(4.66 \mathrm{~g}$ and $1.04 \mathrm{~g}$, respectively) and least root: shoot ratio (0.22). This treatment also recorded highest survival percentage (94.67) which reduced mortality of plants and produced healthy seedlings with highest net returns (Rs 7401/1000 seedlings). Further, it can be concluded that use of soil + vermicompost + vermiculite $(1: 1: 1)$ with $2 \mathrm{~cm}$ cocopeat layer at top of polybags is worth recommendable as both of highest performance of seedling growth of papaya and net returns (Rs 7401/1000 seedlings) which was significantly superior over rest of the treatments.

\section{Introduction}

Papaya (Carica papaya L.) is very wholesome, refreshing and delicious fruit belongs to caricaceae family and its native place is tropical America. Papaya is also called papaw or pawpaw, an ideal fruit for growing in kitchen gardens, backyards of homes as well as in field, especially near the cities or big towns. It is also grown extensively as a filler plant in orchards. And rich source of vitamins. It contains about $2500 \mathrm{IU}$ of vitamin A and $85 \mathrm{mg}$ of vitamin C per $100 \mathrm{~g}$ of pulp. It is also fairly rich in calcium and other minerals. It has high medicinal value. Papain prepared from dried latex of its immature fruits is used in meat tenderizing, manufacture of chewing gum, cosmetics, degumming of natural silk and to give shrink resistance to wool. Papaya juice has an in vitro antiproliferative effect on liver cancer cells, possibly due to lycopene (Asmah et al., 2002). Papaya is a quick growing, continuous fruiting, evergreen plant and requires a good fertile soil or growing media for better growth, development and quality of 
fruits. The use of suitable growing media or substrates for sowing of seeds directly affects the germination, development and functional rooting system. A good growing medium provides sufficient anchorage or support to the plant, serves as reservoir for nutrients and water, allow oxygen diffusion to the roots and permit gaseous exchange between the roots and atmosphere outside the root substrate (Abad et al., 2002). The quality of seedlings is very much influenced by growing media under nursery (Agbo and Omaliko, 2006). The quality of seedlings obtained from a nursery influences re-establishment in the field and the eventual productivity of an orchard (Baiyeri, 2006).

Growing media are an integral part of most horticultural production systems. Soil, vermicompost, vermiculite, perlite, cocopeat etc. are included as different growing media in the present study. The soil is generally used as a basic medium because it is cheapest and easy to procure supplementing of the soil which is aimed to make media more porous while the organic matter (Vermicompost, Vermiculite, Perlite, Cocopeat) is added so as to enrich adequate nutrients for the seedlings.). A growing medium is a substance through which roots grow to extract water \& nutrients. The growing medium also plays an important role in seed germination not only it does act as a support, but also a source of key nutrients for plant growth. The composition of the medium influences the quality of the seedlings (Wilson et al., 2001). Perlite and vermiculite have been used for years to amend professional potting soils made from peat moss (called "soilless" mixes or artificial soils because they literally contain no soil). They also have been used in outdoor mixes, in turfgrass and outdoor planting for gardens. Essentially perlite and vermiculite are used in the horticultural industry because they both provide aeration and drainage, they can retain and hold substantial amount of water and later release it as needed. They are sterile and free from diseases, having a fairly neutral $\mathrm{pH}$ (especially perlite which is neutral), and readily available, non-toxic, safe to use, and relatively inexpensive. Likewise, Vermicompost refers to a mixture of worm casting, organic material, humus, living earthworms, their cocoons and other organisms. Earthworm reduces C: $\mathrm{N}$ ratio, increase humic acid content, cation exchange capacity and water soluble carbohydrates (Talashilkar et al., 1999). Similarly, cocopeat is an agricultural by-product obtained after the extraction of fibre from the coconut husk (Abad et al., 2002). As a growing medium, it can be used to produce a number of crop species with acceptable quantity in the tropics (Yahaya and Mohklas, 1999; Yau and Murphy, 2000). Cocopeat is considered as a growing medium component with acceptable $\mathrm{pH}, \mathrm{EC}$ and other chemical attributes (Abad et al., 2002). Cocopeat has good physical properties, high total pore space, high water content, low shrinkage, low bulk density and slow biodegradation (Evans et al., 1996 and Prasad, 1997).

\section{Materials and Methods}

\section{Climate and weather conditions}

The experiment was laid out at Departmental Nursery and Horticulture farm, S.K.N. College of Agriculture, Jobner, Rajasthan during year 2014-15. The climate of Jobner is typically semi-arid, characterized by extremes of temperature both in summer and winter, low rainfall and moderate relative humidity. Weather parameters play an important role in the growth and developmental process of the crop hence it is important to present climatic variables. The mean daily maximum and minimum temperature during the growing season of papaya fluctuated between 36.3 and $2.40 \mathrm{C}$, respectively and relative humidity ranged from 47 to 82 per cent. The mean 
value of evaporation from USWB class pan ranged from 2.3 to $7.3 \mathrm{hrs} \mathrm{mm}$. There was a total rainfall of $44 \mathrm{~mm}$ during experimentation.

The present experiment consists of 10 treatment combinations with three replications was laid out in CRD with allocation of treatments. The treatments with their combinations and symbols are described as under:- $\mathrm{T}_{0}$ - Soil + Vermicompost (1:1), $\mathrm{T}_{1}$ - Soil + Vermicompost (1:1) with $1 \mathrm{~cm}$ Cocopeat at top, $\mathrm{T}_{2}-$ Soil + Vermicompost (1:1) with $2 \mathrm{~cm}$ Cocopeat at top, $\mathrm{T}_{3}-$ Soil + Vermicompost + Vermiculite (1:1:1), $\mathrm{T}_{4}$ Soil + Vermicompost + Vermiculite $(1: 1: 1)$ with $1 \mathrm{~cm}$ Cocopeat at top, $\mathrm{T}_{5}-$ Soil + Vermicompost + Vermiculite $(1: 1: 1)$ with 2 $\mathrm{cm}$ Cocopeat at top, $\mathrm{T}_{6}-$ Soil + Vermicompost + Perlite $(1: 1: 1), \mathrm{T}_{7}-$ Soil + Vermicompost + Perlite (1:1:1) with $1 \mathrm{~cm}$ Cocopeat at top, $\mathrm{T}_{8}-$ Soil + Vermicompost + Perlite (1:1:1) with $2 \mathrm{~cm}$ Cocopeat at top, $\mathrm{T}_{9}$ Soil + Vermicompost + Vermiculite + Perlite $(1: 1: 1: 1)$. Seeds of papaya cv. 'Pusa Delicious' were procured from Jaipur in $10 \mathrm{~g}$ air-tight polythene packing. "Pusa Delicious"is a gynodioecious variety of papaya with 100 $\%$ productive plants with good fruit yield and quality having excellent taste and good flavour also.

The experimental media consisted of ten different combinations of soil, vermicompost, perlite and vermiculite with two different (1 $\mathrm{cm}$ and $2 \mathrm{~cm}$ ) layer of cocopeat on the top of the polybags. A mixture of growing media was prepared and polythene bags of $10 \times 15 \mathrm{~cm}$ size were filled with mixture as per treatments. Polythene bags holes were made for leakage for gases. Seeds (one in each polybag) were sown at approximately 10-15 $\mathrm{mm}$ deep in the different growing.

The polybags were immediately irrigated after sowing and this was repeated every day with light irrigation for each polybags until seedling emergence takes place. After the completion of germination, the polybags were lightly irrigated once every two days.

\section{Treatment evaluations/measurements}

Data on all seedling growth parameters were measured at 30 days and 45 days after sowing in ten randomly-selected seedlings of each treatment.

\section{Survival percentage}

Survival percentage of papaya seedlings was observed by transplanting them in the field. Ten plants of each treatment were transplanted in field and survivality up to 10 days after transplanting was calculated using the formulae as:

Total number of surviving seedling Survival percentage = --------------------- x 100 Total number of transplanted seedling

Economics of treatments and statistical analysis

The expenditure incurred on all operations and cost of materials and inputs applied to each treatment were taken into account to determine cost of cultivation while the gross return were calculated by multiplying the number of plants of each treatments with sale price of papaya seedlings.

The net returns were calculated by deducting cost of raising the seedlings from gross return for respective treatment. Data collected on different aspects of papaya viz. seedling growth parameters were subjected to statistical analysis (Panse and Sukhatme, 1985).

Significance of difference between means of data was tested through " $F$ " test and critical difference (CD) was worked out wherever, 
"F" value was found to be significant for treatment effect. To elucidate the nature and magnitude of treatment effects summary table along with SEm \pm and $\mathrm{CD}$ at $5 \%$ are given in text of chapter "Experimental Results" and their analysis of variance are given in appendices at the end.

\section{Results and Discussion}

\section{Effect of different growing media on the growth parameters}

A perusal of data given in table 1 revealed that stem girth per plant was also significantly influenced by use of different growing media at 30 and 45 DAS of papaya seedlings. The maximum stem girth per plant at 30 and 45 DAS $(4.49 \mathrm{~mm}$ and $5.90 \mathrm{~mm}$, respectively) was recorded with treatment $\mathrm{T}_{5}$ (Soil + Vermicompost + Vermiculite (1:1:1) with 2 $\mathrm{cm}$ Cocopeat at top). However, minimum was found under $\mathrm{T}_{0}(3.11 \mathrm{~mm}$ and $3.96 \mathrm{~mm}$, respectively). The treatment $\mathrm{T}_{5}$ significantly proved the best over rest of the treatments except $\mathrm{T}_{4}$ which was found to be statistically at par with $\mathrm{T}_{5}$. The increase in stem girth of papaya seedling under $\mathrm{T}_{5}$ was noted 48.84 and 48.99 per cent higher over $\mathrm{T}_{0}$ at 30 and 45 DAS, respectively. Significant differences were observed among the different treatments with regard to seedling growth character like maximum stem girth were observed in treatment $\mathrm{T}_{5}$ which were at par with treatment $\mathrm{T}_{4}$. As discussed that vermicompost, vermiculite and cocopeat provides adequate nutrients and enhances both the physical and biological properties and the water holding capacity of soil (Soegiman, 1982). A similar result was also reported by Bhardwaj, (2014). Further, combined application of vermicompost and cocopeat with vermiculite in the treatment $\mathrm{T} 5$ showed significant effect on seedling growth parameters and plant biomass probably due to the synergistic combinations of these factors improving the physical conditions of the media and nutritional factors (Sahni et al., 2008). It may be due to better nutrient availability leading to higher production of photosynthetically functional leaves in these treatments finally resulting in better girth of seedling (Borah et al., 2008). Similar results were also obtained by Parasana et al., (2014) in mango.

The data pertaining to root character in table 1 clearly indicated that maximum $(9.07 \mathrm{~cm})$ and significantly higher root length and higher number of roots per plant (16.06) were observed in treatment $\mathrm{T}_{5}$ and proved significantly superior over rest of the treatments except $\mathrm{T}_{4}$ which is at par to treatment $T_{5}$ in that regard at 45 DAS of papaya seedling. However, the minimum number of roots (10.20) and minimum root length $(6.50 \mathrm{~cm})$ were recorded under the treatment $\mathrm{T}_{0}$ i.e. soil + vermicompost (1:1). The increase in number of roots per plant was registered 57.45 and 24.02 per cent higher in treatment $\mathrm{T}_{5}$ (Soil + Vermicompost +Vermiculite $(1: 1: 1)$ with $2 \mathrm{~cm}$ Cocopeat at top), over treatment $T_{0}$ and $T_{6}$, respectively and treatment $\mathrm{T}_{5}$ registered 39.54 per cent higher root length of Papaya seedlings than treatment $\mathrm{T}_{0}$ i.e. soil + vermicompost (1:1). From the data of present experimentation also reported that significant differences among the different treatments with regard to seedling growth characters like maximum number of roots per plant and maximum root length were observed in $\mathrm{T}_{4}$ and $\mathrm{T}_{5}$ treatments with soil+ vermicompost+ vermiculite+ cococpeat media. These results are akin to the findings of Bhardwaj (2014) and Abirami (2010) who suggested that since coir dust is low in nutrients when mixed with vermicompost and vermiculite provides a better growth medium for papaya plant establishment. However, the air filled porosity (AFP), easily available water (EAW) and aeration of soil and vermicompost were not at the recommended level, which in turn limit the root growth and lowered the water holding capacity. Therefore, the medium with 
vermicompost, cocopeat and vermiculite were more suitable than soil and vermicompost and perlite. Vermicompost represented hormonelike activity and increased the number of roots, thereby, enhancing nutrient uptake as well as plant growth and development (Alvarez and Grigera, 2005). Similar results were obtained by Yadav et al., (2012) in acid lime using soil: sand: vermicompost: vermiculite: cocopeat $(1: 1: 1: 1: 1)$ media.

It is amply clear from data (Table 1) that use of different growing media had significant effect on fresh weight of roots of papaya seedlings and total weight of plant at 45 days after sowing and fresh weight of Papaya shoots. The maximum fresh weight of shoot $(4.66 \mathrm{~g})$, fresh weight of root $(1.04 \mathrm{~g})$ and maximum and significantly higher total plant weight $(5.70 \mathrm{~g})$ were recorded under treatment $\mathrm{T}_{5}$ (Soil + Vermicompost + Vermiculite $(1: 1: 1)$ with $2 \mathrm{~cm}$ Cocopeat at top), whereas, the minimum fresh weight of shoot $(1.97 \mathrm{~g})$, fresh weight of root $(0.62 \mathrm{~g})$ and total weight of plant were recorded under the treatment $\mathrm{T}_{0}$ i.e. soil + vermicompost (1:1). The treatment $\mathrm{T}_{5}$ was significantly superior over rest of the treatments, but found to be statistically at par with $\mathrm{T}_{4}$.

However, the use of treatment $\mathrm{T}_{5}$ i.e. Soil + Vermicompost + Vermiculite (1:1:1) with 2 $\mathrm{cm}$ Cocopeat at top registered 136.55 per cent higher fresh weight of shoot and total plant weight of papaya seedlings over treatment $\mathrm{T}_{0}$ (soil + vermicompost (1:1) and noted 67.74 per cent higher fresh weight of roots of papaya seedling over treatment $\mathrm{T}_{6}$ i.e. soil + vermicompost + perlite $(1: 1: 1)$. This may be due to favorable conditions for better growth of the seedling, particularly for good development of a root system in earthen media there was less coiling of roots was taken place. Due to more root growth, seedlings absorbed more nutrients and thus produced seedlings with more growth of leaves and increase the photosynthesis which leads to increase fresh weight of seedlings and there by dry weight of seedlings. The beneficial effect on root growth parameters due to media soil + compost + cocopeat (1:1:1) might be due to improved soil texture, structure, porosity, water holding capacity, activity of useful soil micro fauna and flora, maintained soil temperature and improved soil health and nutrient status of medium (Hartmann and Kester, 1997). Further the compost also provides close contact between seed and media increases steady moisture supply facilitates root respiration and encourages overall root growth (Chatterjee and Choudhari, 2007). These findings also indicated that the effect of vermicompost on plant growth and development were not only nutritional but also hormonal and biochemical. The vermicompost increased leaf area and biomass in various plants have been reported by some researchers (Bachman and Metzger, 2008) which are in agreement with findings of current study. Results are obtained in accordance with the results of earlier worker Yadav et al., (2012) in acid lime.

\section{Root: shoot ratio}

A perusal of data given in table 1 revealed that use of different growing media brought out perceptible variation in root: shoot ratio of papaya seedling at 45 days after sowing. Minimum and significantly lower root: shoot ratio $(0.22)$ was observed in treatment $T_{4}$ and $\mathrm{T}_{5}$ over other treatments except treatment $\mathrm{T}_{9}$ which was found to be statistically at par with $\mathrm{T}_{4}$ and $\mathrm{T}_{5}$ during the course of experimentation. However, higher root: shoot ratio (0.36) was found in treatment $\mathrm{T}_{1}$ i.e. soil + vermicompost $(1: 1)$ with $1 \mathrm{~cm}$ cocopeat at top. Treatment $\mathrm{T}_{4}$ and $\mathrm{T}_{5}$ registered 38.89 per cent lower root: shoot ratio as compared to treatment $T_{1}$. Vermicompost provides adequate nutrients and enhances both physical properties and water holding capacity. 
Table.1 Effect of different growing media on seedling growth and yield parameters and economics of papaya

\begin{tabular}{|c|c|c|c|c|c|c|c|c|c|c|}
\hline \multirow[t]{2}{*}{ Treatments } & \multicolumn{2}{|c|}{$\begin{array}{l}\text { Stem girth } \\
\quad(\mathrm{mm})\end{array}$} & \multirow[t]{2}{*}{$\begin{array}{l}\text { Number } \\
\text { of roots }\end{array}$} & \multirow{2}{*}{$\begin{array}{c}\text { Root } \\
\text { length } \\
\text { (cm) }\end{array}$} & \multirow{2}{*}{$\begin{array}{c}\text { Fresh } \\
\text { weight of } \\
\text { shoot }(\mathrm{g})\end{array}$} & \multirow{2}{*}{$\begin{array}{c}\text { Fresh } \\
\text { weight of } \\
\text { roots }(g)\end{array}$} & \multirow{2}{*}{$\begin{array}{c}\text { Total } \\
\text { weight of } \\
\text { plant (g) }\end{array}$} & \multirow{2}{*}{$\begin{array}{c}\text { Root: } \\
\text { shoot } \\
\text { ratio } \\
\end{array}$} & \multirow[t]{2}{*}{$\begin{array}{c}\text { Survival } \\
(\%)\end{array}$} & \multirow{2}{*}{$\begin{array}{l}\text { Net } \\
\text { returns } \\
(\mathrm{Rs})\end{array}$} \\
\hline & $\begin{array}{c}\text { 30 } \\
\text { DAS }\end{array}$ & $\begin{array}{c}45 \\
\text { DAS }\end{array}$ & & & & & & & & \\
\hline$T_{0}-$ Soil + Vermicompost $(1: 1)$ & 3.11 & 3.96 & 10.20 & 6.50 & 1.97 & 0.63 & 2.60 & 0.32 & 79.33 & 6244 \\
\hline$T_{1}$ - Soil + Vermicompost (1:1) with $1 \mathrm{~cm}$ & 3.42 & 4.68 & 13.23 & 6.85 & 2.10 & 0.76 & 2.86 & 0.36 & 84.20 & 6811 \\
\hline Cocopeat at top & & & & & & & & & & \\
\hline$T_{2}$-Soil + Vermicompost $(1: 1)$ with $2 \mathrm{~cm}$ & 3.63 & 4.96 & 15.59 & 7.65 & 2.70 & 0.79 & 3.49 & 0.29 & 86.09 & 7046 \\
\hline Cocopeat at top & & & & & & & & & & \\
\hline $\begin{array}{l}T_{3}-\text { Soil + Vermicompost + Vermiculite } \\
(1: 1: 1)\end{array}$ & 3.93 & 5.12 & 15.29 & 7.73 & 3.82 & 0.93 & 4.75 & 0.24 & 88.67 & 5791 \\
\hline $\begin{array}{l}T_{4}-\text { Soil + Vermicompost + Vermiculite } \\
(1: 1: 1) \text { with } 1 \mathrm{~cm} \text { Cocopeat at top }\end{array}$ & 4.30 & 5.73 & 15.81 & 8.84 & 4.41 & 0.99 & 5.40 & 0.22 & 91.67 & 7031 \\
\hline $\begin{array}{l}T_{5}-\text { Soil + Vermicompost }+ \text { Vermiculite } \\
(1: 1: 1) \text { with } 2 \mathrm{~cm} \text { Cocopeat at top }\end{array}$ & 4.49 & 5.90 & 16.06 & 9.07 & 4.66 & 1.04 & 5.70 & 0.22 & 94.67 & 7401 \\
\hline $\mathbf{T}_{6}-$ Soil + Vermicompost + Perlite $(1: 1: 1)$ & 3.29 & 4.72 & 12.95 & 7.15 & 2.00 & 0.62 & 2.62 & 0.31 & 80.33 & 0290 \\
\hline $\begin{array}{l}T_{7}-\text { Soil }+ \text { Vermicompost }+ \text { Perlite }(1: 1: 1) \\
\text { with } 1 \mathrm{~cm} \text { Cocopeat at top }\end{array}$ & 3.95 & 4.82 & 13.10 & 8.05 & 2.74 & 0.67 & 3.41 & 0.24 & 82.67 & 0945 \\
\hline $\begin{array}{l}T_{8}-\text { Soil }+ \text { Vermicompost }+ \text { Perlite }(1: 1: 1) \\
\text { with } 2 \mathrm{~cm} \text { Cocopeat at top }\end{array}$ & 4.14 & 4.96 & 15.25 & 8.15 & 2.85 & 0.75 & 3.60 & 0.26 & 83.67 & 1751 \\
\hline $\begin{array}{l}T_{9}-\text { Soil + Vermicompost + Vermiculite + } \\
\text { Perlite }(1: 1: 1: 1)\end{array}$ & 4.09 & 5.68 & 15.36 & 8.72 & 3.73 & 0.84 & 4.57 & 0.23 & 86.33 & 0772 \\
\hline SEm \pm & 0.07 & 0.10 & 0.21 & 0.18 & 0.08 & 0.01 & 0.10 & 0.005 & 01.48 & 116.48 \\
\hline $\mathrm{CD}(\mathrm{P}=0.05)$ & 0.23 & 0.29 & 0.62 & 0.55 & 0.25 & 0.05 & 0.30 & 0.017 & 04.38 & 343.63 \\
\hline
\end{tabular}


Combined application of vermicompost and cocopeat have too showed significant effect on seedling growth and plant biomass, perhaps due to the synergistic effect of both these factors. This result is in line with findings of Campos Mota et al., (2009) and Abirami et al., (2010) who suggested that since coir dust was low in nutrients, mixed with vermicompost it provides a better growth medium for plant establishment. However, air filled porosity, easily available water and aeration of vermicompost and Farm Yard Manure were not at the recommended level which, in turn, limited root growth and lowered water-holding capacity. Therefore, medium with vermicompost and cocopeat is better suited than vermicompost alone, because of its better physical properties and higher nutrient levels.

It is apparent from data (Table 1) that use of growing media significantly enhanced the survival percentage of papaya seedlings at 10 days after transplanting in field. The maximum survival percentage (94.67) was recorded with treatment $\mathrm{T}_{5}$ (Soil + Vermicompost + Vermiculite $(1: 1: 1)$ with 2 $\mathrm{cm}$ Cocopeat at top), while minimum was observed under $\mathrm{T}_{0}$ (79.33).

The treatment $T_{5}$ was significantly superior over $\mathrm{T}_{0}$ followed by $\mathrm{T}_{6}, \mathrm{~T}_{7}, \mathrm{~T}_{8}, \mathrm{~T}_{1}, \mathrm{~T}_{2}, \mathrm{~T}_{9}$ and $\mathrm{T}_{3}$ but found to be statistically at par with $\mathrm{T}_{4}$. It registered 19.34 per cent higher survival percentage over treatment $\mathrm{T}_{0}$. Therefore, from the past findings, the medium with vermicompost, cocopeat and vermiculite were more suitable in case of root growth and lowered the water holding capacity than soil and vermicompost and perlite.

These treatment combinations were also helpful in reducing damping off disease in seedling due to proper aeration in root zone of the seedling and provide maximum survival per cent of seedlings because of the better physical properties and enhanced nutrient level in $\mathrm{T}_{4}$ and $\mathrm{T}_{5}$ treatments, growth of seedlings was too fast. It might be due to improved soil porosity, better water contents, drainage, soil permeability and moisture availability.

The seedling ultimately gained better growth and development. It seems that good physical and biological conditions in cococpeat and vermicompost had positive effect on root development, which is helpful in increased survival percentage of seedling in main field after transplanting. Beneficial effect of cocopeat on root system was also observed on nutmeg seedling by Abirami et al., (2010). This may be also due to this favorable media has suitable physical properties and good water holding capacity that supports the vigrous growth of seedlings, better growth of the seedling, particularly for good development of a root system. These results are in close agreement with Shamet et al., (1994).

\section{Economics}

It is evident from the data (Table 1) that growing media Soil + Vermicompost + Vermiculite (1:1:1) with $2 \mathrm{~cm}$ cocopeat at top $\left(\mathrm{T}_{5}\right)$ had maximum and significantly higher net returns in papaya seedlings (Rs 7401 per 1000 seedlings) over rest of the treatments. However, the minimum net returns (Rs 290 per 1000 seedlings) was recorded under the treatment $T_{6}$ followed by $T_{9}, T_{7}$ and $T_{8}$. Application of treatment $T_{5}$ for preparation of papaya seedlings are profitable and showed maximum net return.

This might be due to fact that highest seedling vigour was obtained under this treatment. The higher net returns under this treatment could be ascribed to the lesser cost of treatments and higher healthy seedling. Similar results have also been reported by Bhardwaj (2013). 
It can be concluded that the performance of growing media containing Soil+ Vermicompost+ Vermiculite (1:1:1) with Cococpeat layers at top were found significantly superior over rest of the treatments in all the growth parameters of papaya seedlings. Further, use of growing media as treatment T5 i.e. Soilt Vermicompost+ Vermiculite (1:1:1) with $2 \mathrm{~cm}$ Cococpeat at top is worth recommendable as it fetched comparable net returns (Rs7401/1000 seedlings) which was significantly superior to rest of the treatments.

\section{References}

Abad, M., Noguere, P., puchades, R., Maquieira, A. and Noguera, V. 2002. Physio-chemical and chemical properties of some coconut dusts for use as a peat substitute for containerized ornamental plants. Bioresource Technology, 82: 241245.

Abirami K., Rema J., Mathew, P. A. Srinivasan, V. and Hamza, S. 2010. Effect of different propagation media on seed germination, seedling growth and vigour of nutmeg (Myristica fragrans Houtt.). Journal of medicinal plants research, 4(19): 2054- 2058.

Agbo, CV and Omaliko, CM. 2006. Initiation and growth of shoots of Gongronema latifolia Benth stem cutting in different rooting media. African Journal Biotechnology, 5: 425-428.

Alvarez, R. and Grigera, S. 2005. Analysis of soil fertility and management effects on yields of wheat and corn in the rolling Pampa of Argentina. J. Agron. Crop. Sci. 191: 321-329.

Asmah, R., Rozita, R., Wan, N., L'zzah W.M., Zain, S.E. and Huzaimah, A.S. 2002. Antiproferetive activity of pure lycopene compared to both extracted lycopene and juices from watermelon (Citrullus vulgaris) and papaya (Carica papaya) on humun breast and liver cancer cell. Linus Journal Medicinal Science, 2(2): 55-58.
Bachman, G. R. and Metzger, J. D. 2008. Growth of bedding plants in commercial potting substrate amended with Vermicompost. Bioresource Technol., 99: 3155-3161.

Baiyeri, K. P. and Mbah, B. N. 2006. Effects of soilless and soil-based nursery media on seedling emergence, growth and response to water stress of African Breadfruit (Treculia africana Decne). African Journal of Biotechnology, 5(15): 14051410.

Bhardwaj, R.L. 2013. Effect of nine different propagation media on seed germitination and the initial performance of papaya (Carica papaya L.) seedlings. Journal of Horticultural Science \& Biotechnology, 88(5): 531-536.

Bhardwaj, R.L. 2014. Effect of growing media on seed germination and seedlings growth of papaya cv. Red lady. African Journal of Plant Science, 8(4): 178-184.

Borah, A. S., Nath, A., Ray, A. K., Bhat, R., Maheswarappa, H. P., Subramanian, P., Dileep, M., Sudhakara, K., Santhoshkumar, A. V., Nazeema, K. K. and Ashokan, P. K. 1994. Effect of seed size, rooting medium and fertilizers on the growth of seedlings of silk cotton (Ceiba pentandra Linn.). Indian $J$. Forestry. 17(4): 293-300.

Campos Mota, L., Van Meeteren, U. and Blok, C. 2009. Comparison of physical properties of vermicompost from paper mill sludge and green compost as substitutes for peat based potting media. Acta Hort., 819:227-234.

Chatterjee, R. and Choudhuri, P. 2007. Influence of vermicompost as potting mixture on growth of Moringa (Moringa oleifera Lam.) seedling under Terai Zone of West Bengal. Proc. Nat. Workshop on 'Organic Horticulture' held at BCKV, Mohanpur, 8-10 June, 2007.

Evans, M.R., Konduru, S. and Stamps. R.H. 1996. Source variation in physical and chemical properties of coconut coir dust. Horticulture Science, 3: 965-967.

Hartman, H.T., Kester, D.E., Davies, F.T. and 
Geneve, R.L. 2001. Plant propagation: Principles and practices, 7th Edition, Prentice Hall publishers, New Jersey.

Hartmann, H.T. and Kester, E. 1997. Plant Propagation Principles and Practices. Prentice Hall of India Private Limited, New Delhi.

Mason, J. 2003. Sustainable agriculture. Landlinks Press. PP. 192. ISBN 978-0643-0687-6. Retrieved. 14 may, 2015.

Panse, V.G. and Sukhatme, P.V. 1985. Statistical method for agricultural workers. Fourth edition. Indian Council of Agricultural Research, New Delhi. 381 $\mathrm{P}$.

Parasana, J. S., Leua, H. N. and Ray, N. R. 2013. Effect of different growing Media's mixtures on germination and seedling growth of mango (Mangifera indica L.) cultivars under net house conditions. The Bioscan. 8(3): 897-900

Prasad, M. 1997. Physical, chemical and biological properties of coir dust. Acta Horticulturae, 450: 21-29.

Sahani, S., Sharma, B.K., Singh, D.P., Singh, H.B. and Singh, K.P. 2008. Vermicompost enhances performance of plant growth-promoting rhizobacteria in Cicer arietinum rhizosphere against Sclerocium rolfsii. Crop Protaction, 27: 369-376.

Shamet, G. S., Chauhan, P. S. and Sood, R. 1994. Nursery-studies on potting mixture, mulching and fertilizer requirements of chilgoza pine (Pinus gerardiana Wall.). Indian J. Forestry. 17(3): 225-229.

Sinha, R.K., Heart, S., Valani, D.B., Chauhan, K.A. 2009. Earthworm's vermicompost: A powerful crop nutrient over the conventional compost and protective soil conditioner against the destructive chemical fertilizers for food safety and security. American-Eurasian Journal of Agricultural \& Environmental Sciences, 5: 14-22.

Soegiman 1982. Ilmu tanah. Terjemahan dari. The nature and properties of soils. Buckman and Brady. Bhatara Karya Aksara. Jakarta. 788 hal.

Talashilkar, S.C., bhangarath, P.P. and Metha, V.B. 1999. Changes in chemical properties during composting of organic residues as influenced by earthworm activity. Journal of the Indian society of soil science, 47: 50-53.

Wilson, S.B., Stoffella, P.J. and Graetz, D.A. 2001. Use of compost as a media amendment for containerized production of two subtropical perennials. Journal of Environmental Horticulture, 19(1): 3742.

Yadav, R. K., Jain, M. C. and Jhakar, R. P. 2012. Effect of media on growth and development of acid lime (Citrus aurantifolia Swingle) seedling with or withour Azotobacter. African J. Agric. Res. 7(48):353-358.

Yahya, A., Safie, H. and Mohklas, M.S. 1999. Growth and flowering responses of potted Chrysanthemum in a coir dust-based medium to different rates of slow released fertilizer. Journal of Tropical Agriculture Food Science, 27: 39 - 46.

Yau, P.Y. and Murphy, R.J. 2000. Biograded cococpeat as a horticultural substrate. Acta Horticulturae, 517: 275-27.

\section{How to cite this article:}

Meena, A.K., O.P. Garhwal, Arun Kumar Mahawar and Singh, S.P. 2017. Effect of Different Growing Media on Seedling Growth Parameters and Economics of Papaya (Carica papaya L) cv. Pusa Delicious. Int.J.Curr.Microbiol.App.Sci. 6(6): 2964-2972. doi: https://doi.org/10.20546/ijcmas.2017.606.353 